\title{
Interactions of ammonium, nitrate, and D- and L- amino acids in the nitrogen assimilation of two species of estuarine benthic diatoms*
}

\author{
Wim Admiraal ${ }^{1,3, * *}$, Catherine Riaux-Gobin ${ }^{2}{ }_{r}$ Remi W. P. M. Laane ${ }^{3, * * *}$ \\ ${ }^{1}$ University of Groningen, Department of Marine Biology, PO Box 14, 9750 AA Haren (Gn), The Netherlands \\ ${ }^{2}$ Station Biologique, Place Georges Teissier, F-29211 Roscoff, France \\ ${ }^{3}$ Netherlands Institute of Sea Research, PO Box 59, 1790 AB Den Burg, Texel, The Netherlands
}

\begin{abstract}
Assimilation of D- and L-amino acids by axenic cultures of Navicula salinarum and Amphiprora cf. paludosa was measured by High Performance Liquid Chromatography (HPLC). Ammonium ions at concentrations of 5 to $100 \mu \mathrm{mol} \mathrm{l}^{-1}$ effectively suppressed the utilization of concentrations of $100 \mu \mathrm{mol} \mathrm{l}^{-1}$ of nitrate, but did not eliminate the uptake of amino acids in concentrations of 0.05 to $0.8 \mu \mathrm{mol} \mathrm{l}^{-1}$. N. salinarum assimilated low concentrations of several amino acids parallel with high concentrations of ammonium, whereas $A$. cf. paludosa depleted the concentration of aspartic and glutamic acid more rapidly than that of ammonium. Nitrogen-deprived cultures of both species assimilated spikes of amino acids very rapidly: half of the concentration added was assimilated in $0.5 \mathrm{~h}$. The assimilation of $6 \mathrm{D}$-amino acids was compared with that of the corresponding Lforms; the effect of the isomeric form on the uptake rate differed widely among the amino acids. The possible application of these uptake experiments to interstitial water is discussed.
\end{abstract}

\section{INTRODUCTION}

Marine algae are able to assimilate nitrogen from a variety of sources, e.g. ammonia, nitrate and organic nitrogen. Ammonia and nitrate are commonly regarded as the main source of nitrogen for phytoplankton, whereas the contribution of other sources, e.g. urea, has been measured only in a limited number of cases (McCarthy 1981, Kaufman et al. 1983, Kristiansen 1983, Price et al. 1985). Scarcely any data compare the use made of amino nitrogen and inorganic nitrogenous nutrients by natural assemblages of phytoplankton (Butler et al. 1979, Syrett 1981). Organic sources of nitrogen may be more important for microphytes inhabiting estuarine and marine sediments, than for the phytoplankton. Dissolved free amino acids have

- Publication No. 9 of the project 'Ecological Research of the North Sea'

- Present address: National Institute of Public Health and Environmental Hygiene, PO Box 1, 3720 BA Bilthoven, The Netherlands

-. Present address: Ministry of Transport and Public Works, Tidal Waters Division, PO Box 20907, 2500 EX Den Haag, The Netherlands been found in concentrations as high as $10 \mu \mathrm{mol}^{-1}$ in interstitial waters (Jørgensen et al. 1980) and, moreover, the ability of numerous species of benthic diatoms to use amino acids as a nitrogen source or as a substrate for heterotrophic growth has been demonstrated in axenic cultures (Hellebust \& Lewin 1977. Admiraal \& Peletier 1979, Saks \& Kahn 1979, Admiraal et al. 1984, 1986, Flynn \& Syrett 1986). All the amino acids used in these experiments were in the 'natural' Lform, whereas it can be speculated that D-amino acids are relatively important in the benthos.

The simultaneous utilization of several inorganic and organic nitrogen sources by marine algae raises problems of metabolic regulation. An aspect relatively well studied for phytoplankton is the suppression of nitrate uptake by concentrations of ammonia of ca $1 \mu \mathrm{mol} \mathrm{l^{-1 }}$ (cf. Syrett 1981). Maestrini et al. $(1982,1986)$ demonstrated that oyster-pond plankton and benthic microphytes showed ammonium thresholds for simultanous uptake of ammonium and nitrate at concentrations of 7 to $40 \mu \mathrm{mol} \mathrm{l}^{-1}$ of ammonium. Furthermore, Liu \& Hellebust (1974) showed that amino acids suppressed the nitrate reductase in the neritic Cyclotella cryptica. Recently, Flynn \& Wright (1986) found that high con- 
centrations of L-arginine and ammonia are utilized simultaneously by the semi-planktonic, semi-benthic species Phaeodactylum tricornutum. These observations indicate that neritic and benthic micro-algae are highly versatile in assimilating sources of nitrogen.

Our research aimed to ascertain whether or not nitrate, ammonia and amino acids are simultaneously utilized by truly benthic diatom species. Experiments were performed with $\mathrm{D}$ - and L-amino acids in view of the possibility that both forms are abundant in intertidal sediments. Two estuarine test species were used: Navicula salinarum, which was abundant on an organically polluted mudflat, and Amphiprora cf. paludosa, which was isolated from a sandflat. The interaction of the 3 nitrogen sources was studied in long-term culture experiments and in short-term uptake experiments.

\section{MATERIALS AND METHODS}

Culture technique and analysis. Two benthic diatoms Navicula salinarum Grunow and Amphiprora cf. paludosa W. Smith, were isolated and grown axenically in synthetic seawater medium and were incubated at $14^{\circ} \mathrm{C}$ under $14 \mathrm{~h}$ illumination per day at $100 \mu \mathrm{E}$ $\mathrm{m}^{-2} \mathrm{~s}^{-1}$ (for details see Admiraal et al. 1984). L-amino acids (Sigma) and D-amino acids (Fluka) were added to culture media in concentrations of ca 1 umol $1^{-1}$ and their concentrations were measured by High Performance Liquid Chromatography (HPLC) of o-phthaldialdehyde derivates, following Lindroth \& Mopper (1979). Samples of culture media were stored frozen for a few weeks before analysis. The L-amino acids used were: aspartic acid (asp), glutamic acid (glu), glycine (gly), histidine (his), arginine (arg), serine (ser), alanine (ala), valine (val) and leucine (leu). The following D-amino acids were tested: asp, arg, ser, ala, val and leu.

Diatom cells and media were separated by gentle filtration on glass fibre filters (Whatman GF/C). In. contrast to the observations made by Fuhrman \& Bell (1985) this treatment did not lead to leakage of cellular amino acids (cf. Admiraal et al. 1986).

Nitrate was measured by automated analysis, according to the method described by Strickland \& Parsons (1968). Ammonia forms a weakly fluorescent derivative with $o$-phthaldialdehyde and this was measured by HPLC (Jørgensen et al. 1981). Protein was measured according to Lowry et al. (1951).

Experimental procedures. Two kinds of experiments were carried out: long-term culture experiments (of $14 \mathrm{~d}$ ) and short-term uptake experiments (of $8 \mathrm{~h}$ ). In the growth experiments low concentrations of nitrate-sufficient cells were inoculated into media to which 8 or 9 amino acids had been added, each in a concentration of ca 1 umol $1^{-1}$.
However, most of the nitrogen was obtained from other sources: one culture flask contained ca $100 \mu \mathrm{mol} \mathrm{l}^{-1}$ of ammonia, another ca $100 \mu \mathrm{mol} \mathrm{l}^{-1}$ of nitrate, and the third contained nitrate plus ammonia. Concentrations of ammonia and nitrate used in the media were the same as those commonly observed in interstitial water (cf. Riaux-Gobin 1985). Cell concentrations (counted in microscope counting chambers) and concentrations of nitrogen in the medium were measured, until the cultures reached the stationary phase. Samples from the cultures were taken each day at the same time $(1000 \mathrm{~h})$ to avoid the potential effects of the light-dark cycle.

For the uptake experiments, diatom cells were grown in 2 conditions. Nitrate-sufficient cells were harvested from dilute cultures that initially contained $675 \mu \mathrm{mol} \mathrm{l}^{-1}$ of nitrate. Hence, these cells were saturated with nitrate. Nitrogen-deprived cells were obtained by growing cultures in media that initially contained $30 \mu \mathrm{mol} \mathrm{l}^{-1}$ of nitrate. This small nitrogen source was exhausted after ca $2 d_{i}$ the nitrogen-limitation of the diatoms was evident from their decreased pigmentation. Nitrate-sufficient and nitrogen-starved cells were concentrated aseptically and dispersed in test media containing L- or D-amino acids. The uptake of the amino acids during incubations in the light was measured by HPLC. Control experiments were carried out without adding amino acid and with amino acids in the original culture medium (instead of being added fresh).

\section{RESULTS}

\section{Long-term experiments}

The presence of concentrations of ammonia higher than ca 5 umol $I^{-1}$ effectively suppressed the utilization of nitrate by Navicula salinarum (Fig. 1A) and Amphiprora cf. paludosa (Fig. 2A). L-amino acids were utilized by $N$. salinarum generally parallel with ammonia, even though their combined concentration was an order of magnitude lower than that of ammonia. In the presence of $100 \mathrm{umol}^{-1}$ of nitrate the L-amino acids were assimilated more rapidly than the nitrate (Fig. 1). In A. cf. paludosa the available pool of amino acids, e.g. aspartic acid was more rapidly depleted than that of ammonium even though the concentration of the individual amino acids was only $1 \%$ of the ammonium concentration.

In Navicula salinarum the 8 amino acids tested were taken up in roughly the same way, whereas Amphiprora cf. paludosa was very selective (Fig. 3), assimilating aspartic acid and glutamic acid in a very early stage 

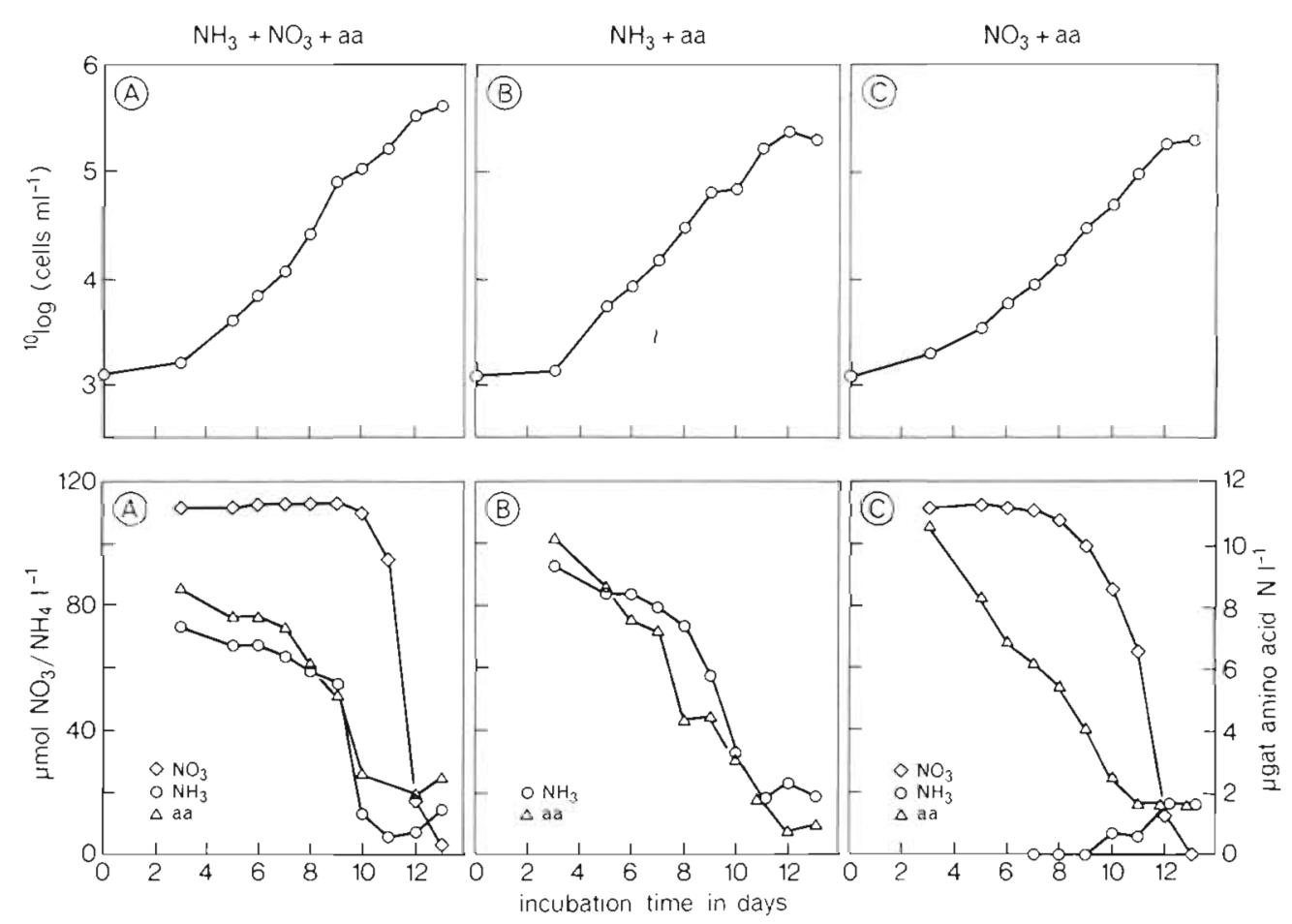

Fig. 1. Navicula salinarum. Development of concentrations of cells (upper plots) and nitrogen compounds (lower plots) in culture media supplied with a mixture of 8 amino acids (aa, totals given on right-hand scale) and with ammonia (B), or nitrate (C), or ammonia plus nitrate $(A)$; concentrations on left-hand scale. Note the difference in scale
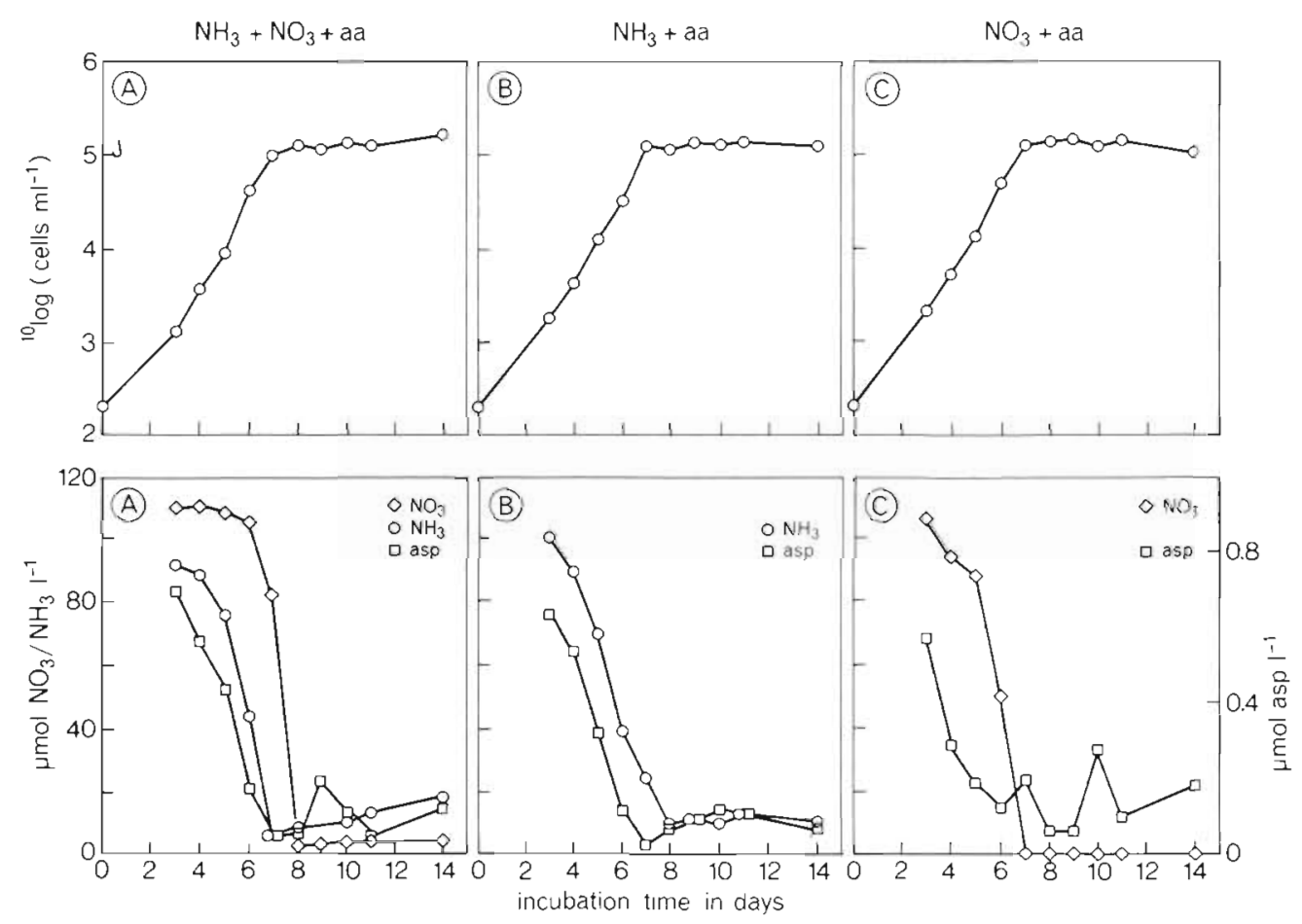

Fig. 2. Amphiprora cf. paludosa. As Fig. 1. Results for amino acids are given for aspartic acid only (for other amino acids see Fig. 3) 


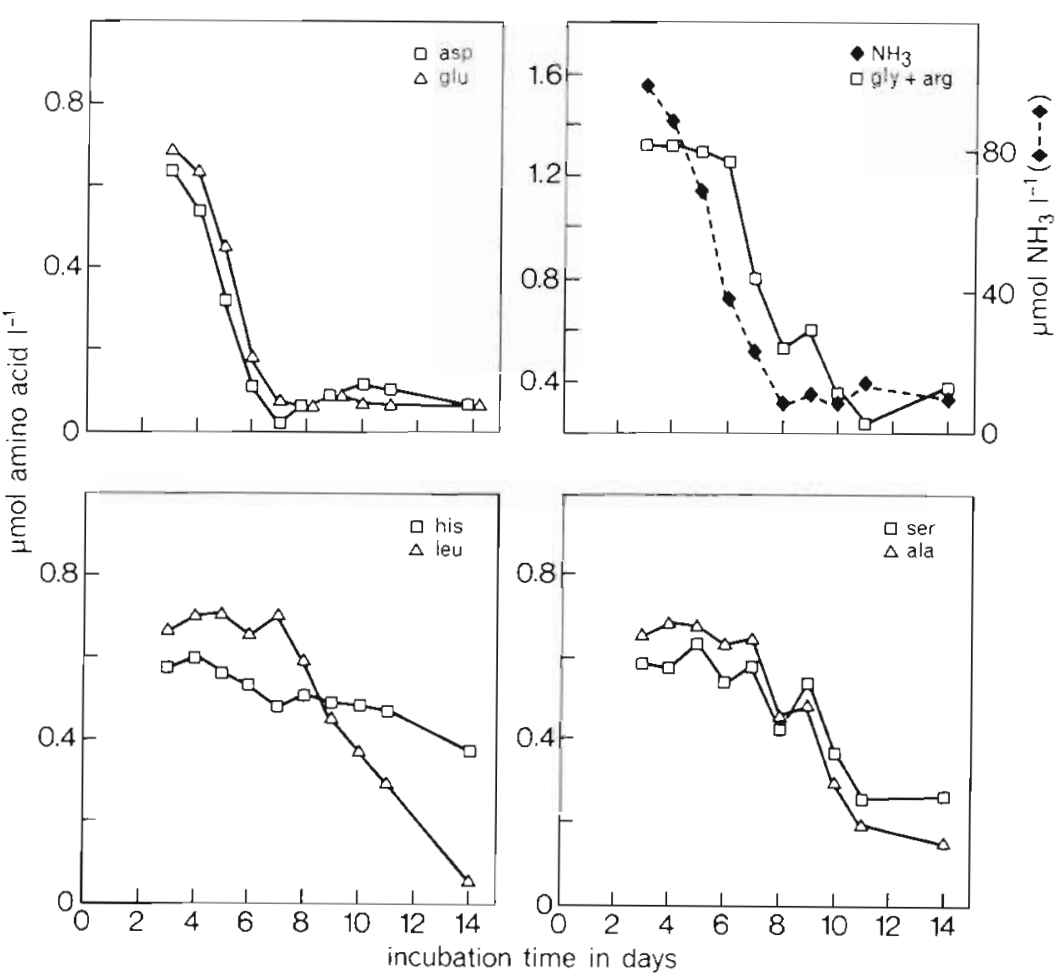

Fig. 3. Amphiprora cf, paludosa. Depletion of ammonia and 8 L-amino acids in cultures with these nitrogen sources (same experiment as in Fig. 2) of growth, and serine, alanine, histidine and leucine in the stationary growth stage only.

Both diatom species seemed to release some ammonia and some amino acids at the end of the exponential growth or when growth stopped. This effect, attributed to the stress effect brought about by the changing nutrient conditions, had been observed earlier in planktonic diatoms (cf. Poulet \& Martin-Jézéquel 1983, Admiraal et al. 1986).

\section{Short-term experiments}

D- and L-amino acids were taken up rapidly by Navicula salinarum not only when the cells were nitrogen-starved, but also when they had adapted to high concentrations of nitrate (Fig. 4). The decrease in the concentrations of amino acid in the media was exponential, consistent with the fact that half-saturation concentrations for uptake in diatoms are generally higher than the concentrations tested here (cf. Hellebust \& Lewin 1977). The rate of amino acid decrease in the media was calculated from the data in Fig. 4 and from similar data on other amino acids and the other diatom species.

Table 1 summarizes the specific rates of decrease in dissolved amino acids, normalized to cell suspensions containing $1 \mathrm{mg}$ protein $\mathrm{l}^{-1}$; the actual concentration of protein varied between 3.5 and $5.8 \mathrm{mg} \mathrm{l}^{-1}$.

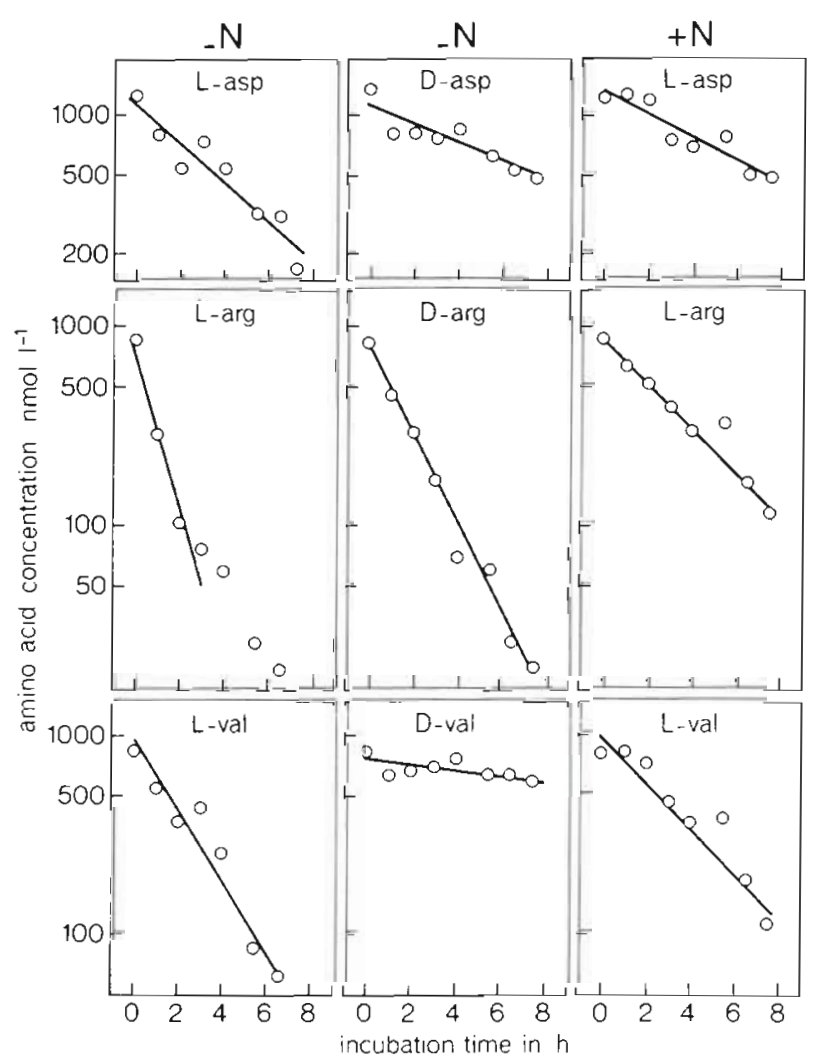

Fig. 4. Navicula salinarum. Short-term uptake of L-and Damino acids in nitrogen-deprived $(-N)$ and nitrate-sufficient $(+N)$ cultures. Results for 3 out of 9 L-amino acids and 3 out of $6 \mathrm{D}$-amino acids are shown 
In nitrogen-starved Navicula salinarum cultures 9 Lamino acids disappeared at a more or less uniform rate of 0.064 to $0.232 \mathrm{~h}^{-1}$ (mg prot $\mathrm{l}^{-1}$ ). In contrast, Amphiprora cf. paludosa was highly active in the uptake of Laspartic acid, L-glutamic acid and L-arginine, whereas other acids were assimilated only slowly (Table 1).

High concentrations of nitrate suppressed the shortterm L-amino acid uptake by Amphiprora cf. paludosa nearly completely, in contrast to the response of Navicula salinarum.

The isomeric form of the amino acid had significant effects on the uptake by the diatoms. The uptake rate of D-aspartic acid and D-arginine acid was ca $60 \%$ that of the corresponding L-forms. For D-alanine, D-serine, $\mathrm{D}$-valine and D-leucine this percentage was 29, 14, 6 and 0 , respectively. So leucine, taken up effectively by the 2 diatom species in the L-form, was not assimilated in the $\mathrm{D}$-form during $7 \mathrm{~h}$ of exposure (Table 1 ).

\section{DISCUSSION}

\section{Antagonism of inorganic and organic nitrogen sources}

The few data available so far indicate that benthic micro-algae regulate the uptake of inorganic and organic nitrogen sources in a way somewhat different from that used by the phytoplankton. The data presented confirm the observation made earlier by Maestrini et al. $(1982,1986)$ that oyster-pond algae, associated with the benthos, assimilate nitrate at considerably higher concentrations of ammonia than do truly planktonic micro-algae. Benthic diatoms, and some neritic forms too, seem to prefer organic nitrogen (e.g. amino acids) to inorganic nitrogen. In the case of nitrate this is illustrated by the response of Navicula salinarum in the present study. In accord with the findings of Flynn \& Wright (1986) this species also utilized L-amino acids in the presence of very high concentrations of ammonia. Flynn \& Wright (1986) also showed that Larginine in high concentrations of $250 \mu \mathrm{mol} 1^{-1}$ suppressed the ammonium uptake. On the other hand, Shah \& Syrett (1982) found that ammonia suppressed the uptake of guanine in the benthic diatom Amphora coffeaeformis. However, generally, the state of nitrogen nutrition of the cells is assumed to be the prime regulator of the rate of amino acid assimilation (Hellebust \& Lewin 1977).

In summary, these observations may indicate that, despite the antagonistic effects, the order of preference of the benthic or neritic diatoms for the nitrogen sources we studied is: amino acids, ammonium and nitrate. The repression or induction of the assimilation of these 3 nitrogen sources deserves further research, such as
Table 1. Decrease in concentrations of L-amino acids (L-aa) and $\mathrm{D}$-amino acids (D-aa) in media of nitrate-depleted $(-N)$ and nitrate-sufficient cultures $(+N$, initially containing 675 $\mu \mathrm{mol} l^{-1}$ of nitrate). Decrease calculated as specific rate of decrease (in $\mathrm{h}^{-1}$ ) from Fig. 4 and other data, and normalized to cultures with $1 \mathrm{mg}$ cell protein $\mathrm{l}^{-1}$-: not tested

\begin{tabular}{|c|c|c|c|}
\hline \multirow{3}{*}{$\begin{array}{l}\text { Amino } \\
\text { acid }\end{array}$} & \multicolumn{2}{|c|}{$-N$} & \multirow{3}{*}{$\begin{array}{c}+\mathrm{N} \\
\mathrm{L}-\mathrm{aa} \\
\left(\mathrm{h}^{-1}[\mathrm{mg} \text { prot }\right. \\
\left.\left.\mathrm{l}^{-1}\right]^{-1}\right)\end{array}$} \\
\hline & L-aa & D-aa & \\
\hline & \multicolumn{2}{|c|}{$\left.\left(\mathrm{h}^{-1}[\mathrm{mg} \text { prot }]^{-1}\right]^{-1}\right)$} & \\
\hline \multicolumn{4}{|c|}{ Navicula salinarum } \\
\hline asp & 0.064 & 0.030 & 0.031 \\
\hline glu & 0.077 & - & 0.040 \\
\hline gly & 0.068 & - & 0.026 \\
\hline his & 0.089 & - & 0.023 \\
\hline $\arg$ & 0.232 & 0.141 & 0.058 \\
\hline ser & 0.093 & 0.013 & 0.041 \\
\hline ala & 0.175 & 0.051 & 0.045 \\
\hline val & 0.111 & 0.007 & 0.056 \\
\hline leu & 0.173 & 0.000 & 0.060 \\
\hline \multicolumn{4}{|c|}{ Amphiprora cf. paludosa } \\
\hline asp & 0.374 & 0.241 & 0.005 \\
\hline glu & 0.305 & - & 0.002 \\
\hline gly & 0.000 & - & 0.000 \\
\hline his & 0.000 & - & 0.000 \\
\hline arg & 0.440 & 0.291 & 0.000 \\
\hline ser & 0.007 & 0.000 & 0.000 \\
\hline ala & 0.009 & 0.000 & 0.000 \\
\hline văl & 0.000 & 0.000 & 0.000 \\
\hline leu & 0.038 & 0.000 & 0.000 \\
\hline
\end{tabular}

the study done by Dortch \& Conway (1984) on the interactions of nitrate and ammonia assimilation in phytoplankton.

\section{Uptake of natural concentrations of amino acids}

North (1975) was probably the first to attempt to measure amino acid uptake from interstitial water by micro-algae. She found that fluorescamine-positive material (mainly amino acids) diminished rapidly when nitrogen-limited Platymonas cells were added. Jørgen-

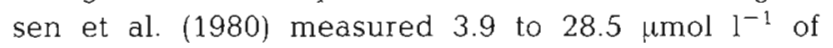
dissolved free amino acids in interstitial water, harvested from a Danish estuary by pressure filtration or centrifugation. We tried to measure the concentrations of amino acids in interstitial waters, harvested by draining in order to avoid squeezing the organisms, and filtered immediately over sterile filters. We found the concentration of amino acid to be at least one order of magnitude lower than Jørgensen et al. (1980) and, more remarkably, the concentrations and composition to be variable. Current techniques of harvesting dissolved free amino acids (cf. Braven et al. 1984, Fuhrman \& Bell 1985) and defining their chemical state (cf. 
Christensen \& Blackburn 1980) seem insufficient to elaborate the initial experiment by North (1975).

Diatoms were shown to assimilate amino acids from their medium at a rate of $\mathrm{ca} 0.1 \mathrm{~h}^{-1}$ (mg prot. $\left.\mathrm{l}^{-1}\right)^{-1}$ (Table 1). Since we estimate the concentrations of diatom protein in the top layers of intertidal sediments in the range of 100 to $1000 \mathrm{mg}$ prot. $\mathrm{I}^{-1}$, one may hypothesize that the in situ turnover rate for amino acids in interstitial water realized by diatoms could be 0.17 to $1.7 \mathrm{~min}^{-1}$ Actually, Christensen \& Blackburn (1980) measured a turnover rate of ca $0.2 \mathrm{~min}^{-1}$ for ${ }^{14} \mathrm{C}$ labelled alanine injected into sediment cores. Hence, diatoms present in superficial sediment layers may participate to a significant extent in the turnover of free amino acids in the benthos.

The isomeric composition of dissolved free amino acids in the sediment is largely unknown. Bada \& Hoopes (1979) found considerable amounts of Dalanine in sedimenting particular material in the top $500 \mathrm{~m}$ water layer of the oceans. Analogously, deposits of estuarine sediments could be enriched in $\mathrm{D}$-amino acids; this prompted us to test the uptake of the 2 isomeric forms. Some of the D-forms were effectively utilized in this study, but there is no proof of actual cellular metabolism using these D-forms. However, Landymore \& Antia (1977) found slow growth of Navicula incerta on D-tyrosine and D-phenylalanine after a long adaptation period. Jung \& Lüttge (1980) found that D-alanine, as well as L-alanine, is taken up by duckweed. However, we found specific differences in the uptake of 6 pairs of D-and L-amino acids. Thus it seems that these differences need further evaluation before they can be used first to characterize the amino acid uptake systems in diatoms and secondly to estimate the relative importance of $\mathrm{D}$-amino acids in the marine environment.

Acknowledgements. Thanks are due to Harry Peletier for the maintenance of the diatom strains and to Joy BurroughBoenisch for correcting the English text. C. R.-G. would like to acknowledge the grant given by the Netherlands Organization for the Advancement of Pure Research (Z.W.O.) and by the French National Centre for Scientific Research (C.N.R.S.).

\section{LITERATURE CITED}

Admiraal, W., Laane, R. W P. M., Peletier, H. (1984). Partıcipation of diatoms in the amino acid cycle of coastal waters; uptake and excretion in cultures. Mar Ecol. Prog. Ser 15: 303-306

Admiraal, W., Peletier, H. (1979). Influence of organic compounds and light limitation on the growth rate of estuarine benthic diatoms. Br. phycol. J. 14: 197-206

Admiraal, W., Peletier, H., Laane, R. W. P. M. (1986). Nitrogen metabolism of marine planktonic diatoms; excretion, assimilation and cellular pools of free amino acids in seven species with different cell size. J exp. mar Biol. Ecol. 98: $241-263$
Bada, J. L., Hoopes, E. A. (1979). Alanine enantiomeric ratio in the combined amino acid fraction in seawater. Nature, Lond. 28: 822-823

Braven, J., Evens, R., Butler, E. I. (1984). Amino acids in sea water. Chemy Ecol. 2: 11-21

Butler, E. I., Knox, S., Liddicoat, M. I. (1979). The relationship between inorganic and organic nutrients in sea water. J. mar biol. Ass. U.K. 59: 239-250

Christensen, D., Blackburn, T H. (1980). Turnover of tracer $\left({ }^{14} \mathrm{C},{ }^{3} \mathrm{H}\right.$ labelled) alanine in inshore marine sediments. Mar. Biol. 58: 97-103

Dortch, Q., Conway, H. L. (1984). Interactions between nitrate and ammonium uptake: variation with growth rate, nitrogen source and species. Mar. Biol. 79: 151-164

Flynn, K. J., Syrett, P. J. (1986). Utilization of L-lysine and Larginine by the diatom Phaeodactylum tricornutum. Mar. Biol. 90: 159-163

Flynn, K. J., Wright, C. R. N. (1986). The simultaneous assimilation of ammonium and L-arginine by the marine diatom Phaeodactylum tricornutum Bohlin. J. exp. mar. Biol. Ecol. 95: 257-269

Fuhrman, J. A., Bell, T. M. (1985). Biological considerations in the measurement of dissolved free amino acids in seawater and implications for chemical and microbiological studies. Mar. Ecol. Prog. Ser. 25: 13-21

Hellebust, J. A., Lewin, J. (1977). Heterotropic nutrition. In: Werner, D. (ed.) The biology of diatoms. Botanical Monographs, Vol. 13. Blackwell, Oxford, p. 169-197

Jorgensen, N. O. G., Lindroth, P., Mopper, K. (1981). Extraction and distribution of free amino acids and ammonium in sediment interstitial waters from the Limfjord, Denmark. Oceanologica Acta 4: 465-474

Jorgensen, N. O. G., Mopper, K., Lindroth, P. (1980). Occurrence, origin, and assimilation of free amino acids in an estuarine environment. Ophelia (Suppl.) 1: 179-192

Jung, K. D., Lüttge, U. (1980). Amino acid uptake by Lemna gibba by a mechanism with affinity to neutral L- and Damino acids. Planta 150: 230-235

Kaufman, Z. G., Lively, J. S., Carpenter, E. J. (1983). Uptake of nitrogenous nutrients by phytoplankton in a barrier island estuary: Great South Bay, New York. Estuar. coast. Shelf Sci. 17: $483-493$

Kristiansen, S. (1983). Urea as a nitrogen source for the phytoplankton in the Oslofjord. Mar. Biol. 74: 17-24

Landymore, A. F., Antia, N. J. (1977). Growth of a marine diatom and a haptophycean alga on phenylalanine or tyrosine serving as a sole nitrogen source. J. Phycol. 13: $231-238$

Lindroth, P., Mopper, K. (1979). High performance liquid chromatographic determination of subpicomole amounts of amino acids by precolumn fluorescence derivatization with o-phthaldialdehyde. Analyt. Chem. 51: 1667-1674

Liu, M. S., Hellebust. J. A. (1974). Utilization of amino acids as nitrogen sources, and their effects on nitrate reductase in the marine diatom Cyclotella cryptica. Can. J. Microbiol. 20: $1119-1125$

Lowry, O. H., Rosebrough, N. J., Farr, A. L., Randall, R. J (1951). Protein measurement with Folin-phenol reagent J. biol. Chem. 193: 265-275

Maestrini, S. Y., Robert, J.-M., Leftley, J. W., Collos, Y. (1986). Ammonium thresholds for simultanous uptake of ammonium and nitrate by oyster-pond algae. $J$. exp. mar Biol. Ecol. 102: 75-98

Maestrini, S. Y., Robert, J. M., Truquet, I. (1982). Simultaneous uptake of ammonium and nitrate by oyster-pond algae. Mar Biol. Lett. 3: 143-153 
McCarthy, J. J. (1981). Nitrogen. In: Morris, I. (ed.) The physiological ecology of phytoplankton. Studies in Ecology, Vol. 7. Blackwell, Oxford, p. 191-233

North, B. B. (1975). Primary amines in California coastal waters utilization by phytoplankton. Limnol. Oceanogr 20: 20-27

Poulet, S. A., Martin-Jézéquel, V (1983). Relationships between dissolved free amino acids, chemical composition and growth of the marine diatom Chaetoceros debile. Mar. Biol. 77: 93-100

Price, N. M., Cochlan, W. P., Harrison, P. J. (1985). Time course of uptake of inorganic and organic nitrogen by phytoplankton in the Strait of Georgia: comparison of frontal and stratified communities. Mar. Ecol. Prog. Ser. 27: $39-53$
Riaux-Gobin, C. (1985). Variations temporelles des sels nutritifs et des pigments chlorophylliens dans l'eau interstitielle dune vase estuarienne de Bretagne Nord. Cah. Biol. mar 26: 109-124

Saks, N. M., Kahn, E. G. (1979). Substrate competition between a salt marsh diatom and a bacterial population. J Phycol. 15: 17-21

Shah, N., Syrett, P. J. (1982). Uptake of guanine by the diatom Phaedactylum tricornutum. J. Phycol. 18: 579-587

Strickland, J. D. H., Parsons, T R. (1968). A practical handbook of seawater analysis. Bull. Fish. Res. Bd Can. 167: $1-311$

Syrett, P. J. (1981). Nitrogen metabolism of microalgae. Can. Bull. Fish. Aquat. Sci. 210:182-210

This article was submitted to the editor; it was accepted for printing on August 13, 1987 